\title{
Ethnoveterinary practice of medicinal plants in Chhatradev Rural Municipality, Arghakhanchi District of Western Nepal
}

\author{
ALOK DHAKAL ${ }^{`}$, SUSHANK KHANAL, MEENA PANDEY \\ Paklihawa Campus, Institute of Agriculture and Animal Science, Tribhuvan University, Rupandehi, Lumbini, Nepal. \\ "email: dhakalalok06@gmail.com
}

Manuscript received: 26 November 2020. Revision accepted: 16 January 2021.

\begin{abstract}
Dhakal A, Khanal S, Pandey M. 2021. Ethnoveterinary practice of medicinal plants in Chhatradev Rural Municipality, Arghakhanchi District of Western Nepal. Nusantara Bioscience 13: 29-40. The use of medicinal plants is a traditional system in treating domestic animals in Nepal. This study was done to investigate and document knowledge about using different plants with medicinal value to cure different animal ailments in Chhatradev Rural Municipality, Arghakhanchi district of western Nepal. A total of 100 elderly people rearing domestic animals and having traditional knowledge of ethnoveterinary plants were selected for interview. A semistructured questionnaire was employed, and interviews were conducted for addressing detailed ethnoveterinary information. The uses of 103 plant species belonging to 56 families were documented for the treatment of 21 animal ailments. Fabaceae was found to be a dominant family with 10 plant species followed by Poaceae ( 8 species). The most commonly used plant parts were leaf, seed, and fruit. Herbs were dominant with 44 plant species followed by trees (32 species), shrubs (14 species), and climbers (13 species). The wide application of the medicinal plants as the form of paste formulation was observed for 41 plant species, while 25 plant species were used as powder formulation followed by Juice ( 21 species), raw ( 20 species), decoction (19 species), infusion ( 5 species), and roasted formulation ( 3 species). Oral route was the most common route followed by dermal and ocular. It was found that the informant consensus factor (ICF) values varied from 0.858 to 0.96. A high informant consensus factor was found for ailment of reproductive category $(0.96)$ followed by respiratory $(0.957)$, gastrointestinal $(0.949)$ while the least was in urinary problem category $(0.858)$. The highest citation frequency was found for Trachyspermum ammi (L.) Sprague (247) followed by Myristica fragrans Houtt. (111), Sesamum indicum L. (109), Saccharum officinarum L. (107) and Zea mays L. (97). The wide use and rich knowledge of ethnoveterinary practice were found in the study area. This study might be handy to discover useful ethnopharmaceutical agents applicable in the livestock industry. Conservation programs should be done from the government level and study on the use of medicinal plants for treating animal diseases is recommended.
\end{abstract}

Keywords: Animal care, indigenous knowledge, livestock, Nepal, traditional veterinary healers

\section{INTRODUCTION}

Medicinal plants have been used by humans for human as well as animal ailments, and disease treatment from the earliest history of human beings (Bartha et al. 2015; Petrovska 2012). Ethnoveterinary medicine is the traditional approach relating to the treatment and maintenance of animal health care. It is following folklore beliefs, skills, and practices of people by using locally available plant species (Hassan et al. 2017; Katerere and Luseba 2010; Ryan 2014). These medicinal plants discovered by traditional societies are an important source of new potential therapeutic drugs (Pan et al. 2014).

The current studies have the equal concern of improving human medication as well as animal health by the use of locally available medicinal plants. In contrast to modern veterinary medicine, ethnoveterinary practices have been established through trial and error methods with deliberate experimentation by farmers in the fields (Baskota and Doj Raj 2013). The increase in the cost of caring for and maintaining animal health in modern health facilities has made researchers increase their enthusiasm towards the study of ethnoveterinary medicinal plants
(Phondani et al. 2010). Nepal is predominantly an agricultural county with about $90 \%$ of people in rural areas own livestock as a part of their livelihood (MOAD 2017). For a developing country like Nepal with a huge number of poor farmers, ethnoveterinary practice for animal treatment is a sustainable way of veterinary medicine practice in the new era (NAVS 2015). The indigenous use of ethnoveterinary medicinal plants is of great boon to the developing countries because of its quick accessibility and affordability where there is no easy access to the modern veterinary care facilities (Aziz et al. 2018). Although ethnoveterinary medicinal plants carry great potential in the treatment of the animals, proper documentation of the plants has not been done in the majority of the rural areas of Nepal. The knowledge has been transferred from one to the next generation only verbally or orally (Raut and Shrestha 2012) which is not a dependable way to preserve the knowledge of ethnoveterinary practices. The ease of access to modern health facilities, increase in development of socio-economic aspects, failure to transfer indigenous knowledge regarding medicinal plants, change in technology, and unplanned urbanization have led the use of 
ethnoveterinary medicinal plants in a great threat (Subedi 2017; Weckmüller et al. 2019).

As ancient practice of herbal treatment of livestock diseases are still significant today, and are still used by many farmers, veterinarian, Ayurvedic physicians, and Vaidyas, so that this study was conducted to investigate, and document local knowledge about the use of different plants with medicinal value in Chhatradev Rural Municipality of Arghakhanchi district in Nepal. The objectives to carry this study were (i) to document the plants with medicinal values used in the treatment of various ailment category of the animals, (ii) to disseminate the formulation technique and the plant part used, (iii) to determine the informant consensus factor and (iv) to record the plant species with the highest citation frequency. This study will be a useful resource for the conservationist, veterinarians, phytochemists, and Ayurvedic physicians to conduct pharmacological studies in the coming days, and will be a valuable asset for the farmers for the treatment of animals health.

\section{MATERIALS AND METHODS}

\section{Study area}

Chhatradev Rural Municipality is a rural municipality of Arghakhanchi district located in Lumbini province of Nepal. It has an area of 87.62 square kilometres. The climate is tropical to subtropical type with cool and humid. The majority of people are Brahman, Chhetri, Magar, and other ethnic groups like Kumal, Gurung, Kami, Damai, Sarki, Thakuri, Sanyasi, Newar, Badi, and others (CBS 2012). The rural people are not only dependent on forests and natural vegetation to fulfill their daily needs of fuelwood, fodder, grasses, leaf litter, etc., but also for the treatment of ailments and diseases using medicinal plants. The map of the study area is shown in Figure 1. People here are acquainted more with the traditional ethnobotanical knowledge, and are well practitioner of folk beliefs.

\section{Data collection}

The data were collected from July to September 2020. A total of 100 elderly, knowledgeable, and experienced persons rearing domestic animals who had traditional knowledge of ethnoveterinary plants were selected. A questionnaire was prepared, and interviews were taken from them addressing detailed ethnoveterinary information. The interview process followed international codes of ethics (ISE 2006).

\section{Plant specimen collection and identification}

Some of the collected specimens were identified in the field, whereas others were identified with the help of standard botanical literature. Nomenclature of the identified species follows standard kinds of literature (Aryal et al. 2016; DPR 2015; IUCN Nepal 2000; POWO 2017).

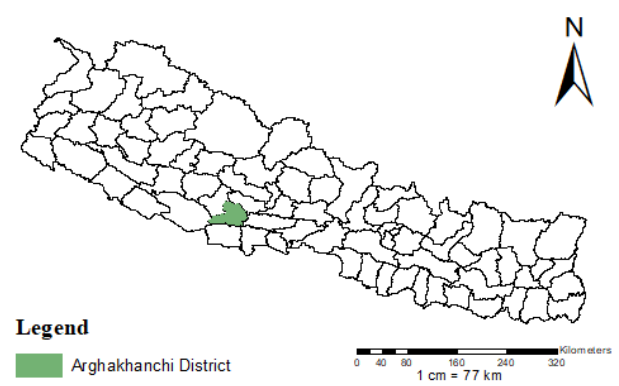

A
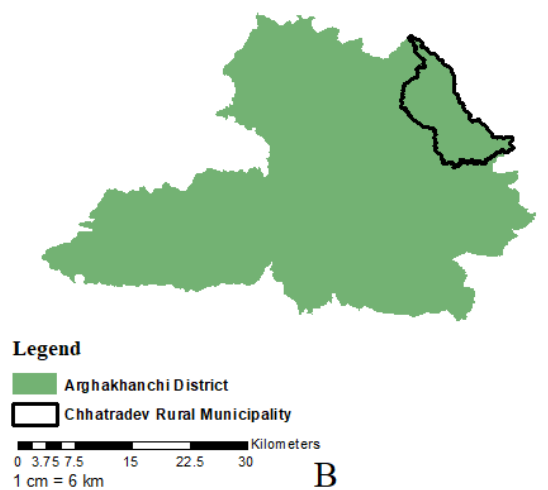

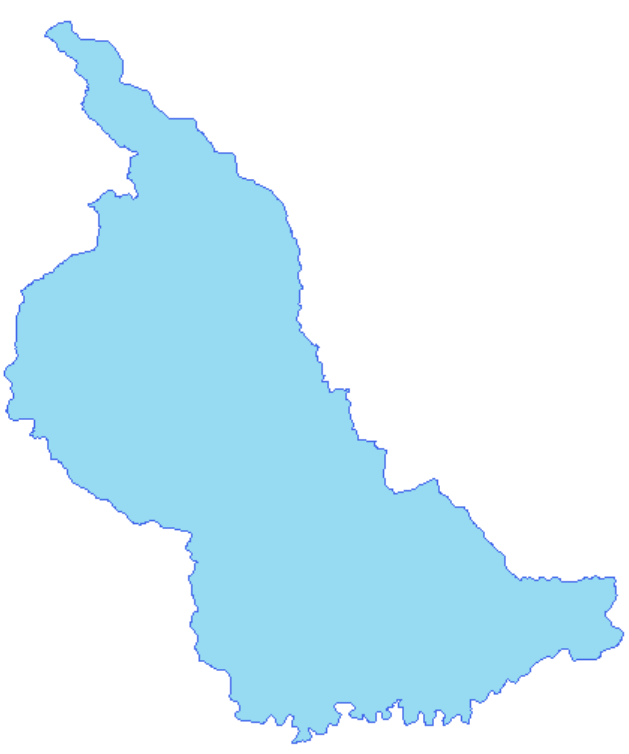

Legend

$\square$ Chhatradev Rural Municipality

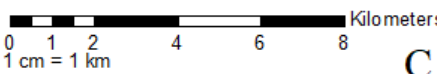

Figure 1. A. Map of Nepal showing Arghakhanchi districts with green color and other hollow ones are other districts. B. Map of Arghakhanchi district showing Chhatradev Rural Municipality. C. Map of Chhatradev Rural Municipality 


\section{Data organization}

After completion of fieldwork, data entry was done in Microsoft Excel 2016. The life form of the medicinal plants was classified into herbs, shrubs, trees, and climbers. The plant part utilized was classified into bark, bulb, flower, fruit, latex, leaf, rhizome, root, seed, stem, tuber, and whole plant. The preparation technique was classified into different groups, i.e., powder, paste, juice, infusion, raw, decoction, and roast. Route of administration was categorized into oral, dermal, and ocular. The uses of medicinal plants were categorized into ten major categories: reproductive, respiratory, gastrointestinal, antipyretic, parasitic, general weakness, eye, dermatological, osteological, and urinary problems.

\section{Data analysis}

For analysis of socio-demographic profile, Microsoft Excel 2016 was used.

\section{Informant consensus factor (ICF)}

To determine the agreement among informants in terms of the use of plants, the Informant Consensus Factor (ICF) was calculated (Heinrich et al. 1998). It was followed in the number of Ethnoveterinary studies of Medicinal Plants (Adeniran et al. 2020; Tariq et al. 2014).

$$
\mathrm{ICF}=\frac{\mathrm{Nur}-\mathrm{Nt}}{\mathrm{Nur}-1}
$$

Where; ICF $=$ Informants consensus factor, Nur $=$ number of use reports from informants for a particular plant-use category; $\mathrm{Nt}=$ number of taxa or species that are used for that plant use category for all informants.

The result of this index ranges from 0 to 1 . ICF values are low if plants are chosen randomly or if there is no exchange of information about their use among informants, and approach one (1) when there is a well-defined selection criterion in the community and/or if information is exchanged between informants.

\section{Citation frequency (Cf\%)}

$\mathrm{Cf}$ of medicinal plants is useful to determine the most commonly used medicinal plants in the study area.

$$
\mathrm{Cf} \%=\frac{\mathrm{n}}{\mathrm{N}} \times 100
$$

Where; $\mathrm{n}$ refers to the number of times a particular species was mentioned, $\mathrm{N}$ refers to the total number of times that all species were mentioned.

\section{RESULTS AND DISCUSSION}

\section{Socio-demographic profile of the informants and their domestic animal composition}

Out of 100 informants, more than half of the respondents were male (58) while there were 42 female respondents. Most of the interviewees (72) were older than 50 years and 28 interviewees were between 35-50 years old. Agriculture was the main source of household income to 70 respondents while 19 people had government services, and 11 had remittance as the way to make a living. Among the informants, there were not any illiterate while the majority (70) of the informants had gained primary education, 19 informants had gained secondary education, and the rest (11 informants) had got other higher forms of education (Table 1). Livestock (Buffalo, Goat, Cow, Poultry) were important economic sources of informants. The majority of the respondents (98) kept buffalo, 81 respondents kept goats, 28 respondents kept poultry and 4 respondents kept cow with their total number 191, 237, 191, and 7 respectively (Figure 2).

\section{Source of ethnoveterinary knowledge}

The majority of the respondents received the knowledge of ethnoveterinary use of plants from their ancestors whereas some came from neighbors, newspapers, and radio. Elderly people, mainly male, were rich in ethnoveterinary knowledge, and more concerned about the conservation of plants than younger people. This observation has also been reported by Khan et al. (2015).

Table 1. Socio-demographic characteristics of respondents

\begin{tabular}{lc}
\hline \multicolumn{1}{c}{ Description } & Frequency \\
\hline Age & 28 \\
$35-50$ & 72 \\
$>50$ & \\
Gender & 42 \\
$\quad$ Female & 58 \\
Male & \\
Educational level & 70 \\
$\quad$ Primary & 19 \\
$\quad$ Secondary & 11 \\
Others & \\
Primary occupation & 70 \\
$\quad$ Agriculture & 19 \\
Government services & 11 \\
$\quad$ Remittance &
\end{tabular}

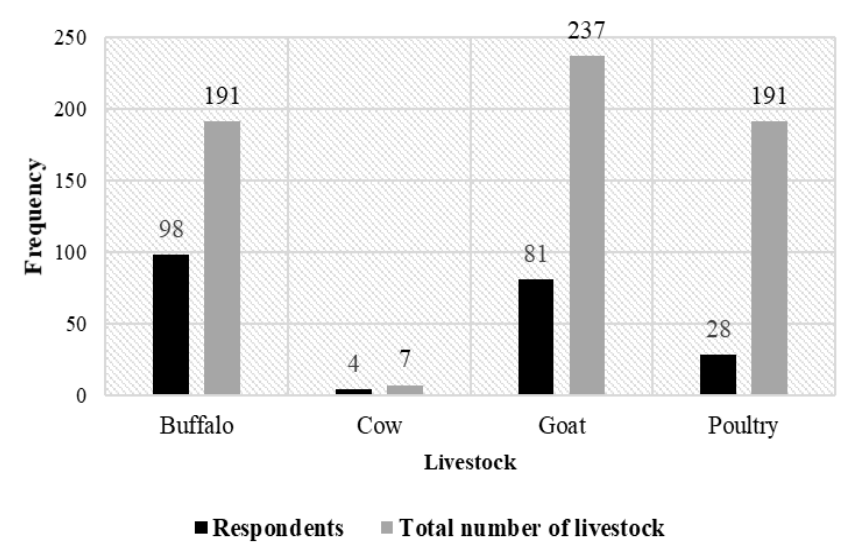

Figure 2. Respondents with the number of their livestock in the study area 
Table 2. List of the ethnoveterinary medicinal plants identified in the study area

\begin{tabular}{|c|c|c|c|c|c|c|c|}
\hline Botanical name & Family & Local name & $\begin{array}{l}\text { Life } \\
\text { form }\end{array}$ & Part used & $\begin{array}{l}\text { Form of } \\
\text { medication }\end{array}$ & Route & Method of use and application \\
\hline \multirow[t]{2}{*}{ Justicia adhatoda L. } & \multirow[t]{2}{*}{ Acanthaceae } & \multirow[t]{2}{*}{ Asuro } & \multirow[t]{2}{*}{ Shrub } & Whole plant & Decoction & Oral & $\begin{array}{l}\text { Decoction prepared from the whole plant is given twice a day orally until cure of } \\
\text { common cold }\end{array}$ \\
\hline & & & & Leaf & Paste & Dermal & $\begin{array}{l}\text { Leaves are ground to make a paste and mixed with turmeric powder to cure } \\
\text { ectoparasite }\end{array}$ \\
\hline Achyranthes aspera $\mathrm{L}$. & Amaranthaceae & Datyun & Herb & Whole plant & Raw & Oral & Fed as a feed to cure endoparasite \\
\hline Chenopodium album $\mathrm{L}$. & Amaranthaceae & Bethe & Herb & Whole plant & Juice & Oral & The whole plant is crushed and obtained juice is given orally to treat dysentery \\
\hline Allium sativum $\mathrm{L}$. & Amaryllidaceae & Lasun & Herb & Bulb & Paste & Oral & $\begin{array}{l}\text { Allium sativum } \mathrm{L} \text {. and Mentha arvensis } \mathrm{L} \text {. are mixed in a ratio of } 1: 2 \text {. They are } \\
\text { crushed and given to animal to cure diarrhea }\end{array}$ \\
\hline & & & & & & Dermal & Bulb is crushed with camphor to make paste and applied to the wound. \\
\hline Mangifera indica $\mathrm{L}$. & Anacardiaceae & Aap & Tree & Bark & Powder & Dermal & The bark is dried then ground with camphor and applied to the burn area \\
\hline Rhus javanica $\mathrm{L}$. & Anacardiaceae & Bhakkimlo & Tree & Fruit & Infusion & Oral & $\begin{array}{l}\text { Ripe fruits are soaked in water, and water is given twice a day to animal by mixing } \\
\text { with curd to treat diarrhea and dysentery }\end{array}$ \\
\hline Semecarpus anacardium $\mathrm{L}$. & Anacardiaceae & Bhela & Tree & Fruits & Juice & Dermal & Fruit is ground with mustard oil and applied to wound \\
\hline Centella asiatica (L.) Urb. & Apiaceae & Ghodtapre & Herb & Whole plant & Raw & Oral & The whole plant is fed to treat urinary disorders. \\
\hline $\begin{array}{l}\text { Trachyspermum ammi (L.) } \\
\text { Sprague }\end{array}$ & Apiaceae & Juwano & Shrub & Seed & $\begin{array}{l}\text { Powder, } \\
\text { Decoction }\end{array}$ & Oral & $\begin{array}{l}\text { The required amount of dry seed is crushed and fed with water, cornflour meal. It } \\
\text { can also be boiled in water and fed twice a day to cure cough, diarrhea, and fever. } \\
\text { Whereas dried seeds of Trachyspermum ammi (L.) Sprague, Sesamum indicum L. } \\
\text { and Myristica fragrans Houtt. are crushed to make powder, and given to animals by } \\
\text { mixing with cornflour to cure constipation and increase milk production. }\end{array}$ \\
\hline $\begin{array}{l}\text { Calotropis gigantea (L.) } \\
\text { Dryand. }\end{array}$ & Apocynaceae & Aank & Tree & Leaf & Paste & Dermal & Lightly crushed leaves are warmed on fire and kept on swelling joints \\
\hline $\begin{array}{l}\text { Holarrhena pubescens } \\
\text { Wall. ex G.Don }\end{array}$ & Apocynaceae & Indrajau & Tree & Bark & Decoction & Oral & $\begin{array}{l}\text { Decoction obtained from bark is given to the livestock to treat constipation, } \\
\text { diarrhea, and dysentery }\end{array}$ \\
\hline $\begin{array}{l}\text { Marsdenia tenacissima } \\
\text { (Roxb.) Moon }\end{array}$ & Apocynaceae & Bilajor & Climber & Root & Paste & Dermal & Root paste is applied on swelling bone area \\
\hline Acorus calamus $\mathrm{L}$. & Araceae & Bojho & Herb & Rhizome & Paste & Dermal & Paste prepared from the rhizomes is applied to the body of animals to remove lice \\
\hline $\begin{array}{l}\text { Colocasia esculenta (L.) } \\
\text { Schott }\end{array}$ & Araceae & Karkalo & Herb & Leaf, Stem & Decoction & Oral & $\begin{array}{l}\text { Small pieces are made by cutting them and given to animal by cooking with } \\
\text { cornflour to cure endoparasite and diarrhea }\end{array}$ \\
\hline Agave cantula Roxb. & Asparagaceae & Ketuki & Herb & Leaf & $\begin{array}{l}\text { Decoction } \\
\text { Juice }\end{array}$ & Oral & $\begin{array}{l}\text { Juice extracted from boiled leaf is given orally to cure fever } \\
\text { Leaves are ground to obtain juice and fed for any urinary related problem }\end{array}$ \\
\hline Aloe vera (L.) Burm.f. & Asphodelaceae & Ghyu kumari & Herb & Leaf & Raw & Dermal & Jelly portion of leaf is rubbed in burn area and cure mastitis \\
\hline Begonia picta Smith & Begoniaceae & Magarkanche & Herb & Root & Infusion & Ocular & Water obtained after infusion of the root is applied to treat conjunctivitis of buffalos \\
\hline $\begin{array}{l}\text { Oroxylum indicum (L.) } \\
\text { Kurz }\end{array}$ & Bignoniaceae & Tatahalo & Tree & Bark & Powder & Oral & $\begin{array}{l}\text { Bark of Oroxylum indicum (L.) Kurz and Schima wallichii (DC.) Korth. are dried, } \\
\text { then ground to obtain powder, and fed to cure diarrhea }\end{array}$ \\
\hline & & & & Leaf, seed & Paste & & Fresh leaves and seeds are ground to make a paste, and fed to cure urinary problem \\
\hline $\begin{array}{l}\text { Cynoglossum zeylanicum } \\
\text { Thumb. ex. Lehm. }\end{array}$ & Boraginaceae & Bhere kuro & Herb & Whole plant & Powder & Ocular & Powder obtained from dried plant is blown to eye problem \\
\hline Brassica nigra $\mathrm{L}$. & Brassicaceae & Tori & Herb & Seed & $\begin{array}{l}\text { Paste } \\
\text { Juice } \\
\text { Paste }\end{array}$ & $\begin{array}{l}\text { Dermal } \\
\text { Oral } \\
\text { Dermal }\end{array}$ & $\begin{array}{l}\text { Paste of plant mixed with water and applied to cure skin scabies and wound } \\
\text { The mustard oil is directly fed to cure endoparasite and uterus prolapse } \\
\text { Mustard cake is mixed with maize flour, and fed to increase milk production } \\
\text { Mustard cake is applied to cure skin scabies }\end{array}$ \\
\hline
\end{tabular}




\begin{tabular}{|c|c|c|c|c|c|c|c|}
\hline Cannabis sativa $\mathrm{L}$. & Cannabaceae & Ganja & Herb & Leaf, seed & Powder & Oral & $\begin{array}{l}\text { The mixture of leaf and seed is ground then drenched with water to cure diarrhea, } \\
\text { fever, and urinary related problems }\end{array}$ \\
\hline $\begin{array}{l}\text { Crateva unilocularis } \\
\text { Buch.-Ham }\end{array}$ & Capparaceae & Simlikan & Tree & Leaf, stem & Raw & Oral & The grass and edible stem are directly fed to cure endoparasite \\
\hline Carica papaya $\mathrm{L}$. & Caricaceae & Mewa & Tree & Seed & Powder & Oral & $\begin{array}{l}\text { Matured dry seeds are crushed to make powder, and given orally to cattle once a day } \\
\text { for up to six days against internal parasites }\end{array}$ \\
\hline $\begin{array}{l}\text { Terminalia bellirica } \\
\text { (Gaertn.) Roxb. }\end{array}$ & Combretaceae & Barro & Tree & Fruit & Powder & Oral & Fresh fruit is given orally to treat diarrhea \\
\hline Commelina benghalensis $\mathrm{L}$. & Commelinaceae & Khane jhar & Herb & Leaf & Paste & Dermal & $\begin{array}{l}\text { Paste obtained from leaf is made and applied locally on fresh wounds in animals as } \\
\text { antiseptic }\end{array}$ \\
\hline \multirow[t]{3}{*}{ Artemisia indica $\mathrm{L}$. } & Compositae & Titepati & Herb & Leaf & Juice & Dermal & Leaf and kerosene are crushed to make a juice and applied to cure ectoparasite \\
\hline & & & & Whole plant & Decoction & Oral & $\begin{array}{l}\text { Artemisia indica L., Azadirachta indica A.Juss. and Melia azedarach L. (Leaf) are } \\
\text { taken and cut into pieces, mixed with cornflour, cooked, and fed to cure endoparasite }\end{array}$ \\
\hline & & & & Leaf & Paste & Dermal & $\begin{array}{l}\text { Leaf and camphor are crushed to make a paste and applied in a wounded area twice } \\
\text { a day }\end{array}$ \\
\hline Tagetes patula $\mathrm{L}$. & Compositae & Sayapatri & Herb & Root & Paste & Oral & Fresh roots are ground and fed to treat urinary problem \\
\hline Cuscuta reflexa Roxb. & Convolvulaceae & Aakash beli & Climber & Stem & Infusion & Oral & $\begin{array}{l}\text { Stem along with local tomato, ghee, butter, and curd is placed in a copper vessel } \\
\text { over a night. It is given orally to cattle against endoparasites }\end{array}$ \\
\hline Cucumis sativus $\mathrm{L}$. & Cucurbitaceae & Kakro & Climber & Seed & Powder & Oral & $\begin{array}{l}\text { Dried seeds are crushed to make powder and fed by drenching with water to cure } \\
\text { urinary problems }\end{array}$ \\
\hline Cucurbita maxima Duchesne & Cucurbitaceae & Farsi & Herb & Fruit & Decoction & Oral & Ripen yellow pumpkin is cooked with cornflour and feed to cure mastitis \\
\hline \multirow[t]{2}{*}{ Solena heterophylla Lour. } & Cucurbitaceae & Golkankri & Climber & Root & Paste & Dermal & The paste prepared from the root is applied to cure mastitis \\
\hline & & & & Whole plant & Raw & Oral & $\begin{array}{l}\text { The whole plant is considered a nutritious feed, and also used to increase milk } \\
\text { production }\end{array}$ \\
\hline \multirow[t]{2}{*}{$\begin{array}{l}\text { Trichosanthes cucumerina } \\
\text { L. }\end{array}$} & Cucurbitaceae & Chichinno & Climber & Seed & Powder & Oral & $\begin{array}{l}\text { Dried seeds are crushed to make powder and fed by mixing with turmeric to cure } \\
\text { endoparasite }\end{array}$ \\
\hline & & & & Fruit & Raw & & Fruit is fed raw to treat mastitis and removing the placenta \\
\hline Cyperus difformis $\mathrm{L}$. & Cyperaceae & Mothe Jhar & Herb & Root & Paste & Oral & The root nodules are crushed and fed to cure any urinary related problem \\
\hline $\begin{array}{l}\text { Dioscorea deltoidea Wall. } \\
\text { ex Griseb. }\end{array}$ & Dioscoreaceae & Bhayakur & Climber & Tuber & Juice & Oral & Juice obtained from tuber is given twice a day is to treat constipation \\
\hline $\begin{array}{l}\text { Equisetum debile Roxb. ex } \\
\text { Vaucher }\end{array}$ & Equisetaceae & Kurkure Jhar & Herb & Stem & Paste & Dermal & Paste obtained from stem is applied externally on fractured bone \\
\hline $\begin{array}{l}\text { Albizia procera (Roxb.) } \\
\text { Benth. }\end{array}$ & Fabaceae & Jukret & Shrub & Bark & Powder & Oral & $\begin{array}{l}\text { Dried bark is crushed to make powder, and drenched with water to cure bone related } \\
\text { problems }\end{array}$ \\
\hline \multirow[t]{2}{*}{ Bauhinia purpurea $\mathrm{L}$. } & Fabaceae & Koiralo & Tree & Leaf & Raw & Oral & Oral administrations of leaves as feed to enhance lactation \\
\hline & & & & Bark & Decoction & Dermal & Slightly warm stem bark decoction is used to cure wounds \\
\hline Cassia fistula $\mathrm{L}$. & Fabaceae & Rajbrikshya & Tree & Fruit, seed & Powder & Oral & Dried seed and fruit are ground to make powder, and fed to cure urinary problem \\
\hline Dalbergia sissoo Roxb. & Fabaceae & Sissoo & Tree & Leaf & Juice & Oral & $\begin{array}{l}\text { Leaf is crushed to obtain juice, and then mixed with churning curd, and fed to cure } \\
\text { diarrhea }\end{array}$ \\
\hline Erythrina stricta Roxb. & Fabaceae & Phaledo & Tree & Bark & Infusion & Dermal & Bark is soaked in water and applied over the body to treat scabies \\
\hline Lens culinaris Medikus & Fabaceae & Masuro & Herb & Seed & Decoction & Oral & $\begin{array}{l}\text { Seeds are cooked with maize flour and given to animal twice a day to increase milk } \\
\text { production }\end{array}$ \\
\hline Mimosa pudica $\mathrm{L}$. & Fabaceae & Lajjawati jhar & Herb & Whole plant & Raw & Oral & Fed whole plant to animal as feed to cure uterus prolapse \\
\hline $\begin{array}{l}\text { Phanera vahlii (Wight \& } \\
\text { Arn.) Benth. }\end{array}$ & Fabaceae & Bharla & Climber & Bark & Powder & Oral & $\begin{array}{l}\text { Dried bark is ground to make powder and fed with honey to treat joint-related } \\
\text { problem }\end{array}$ \\
\hline
\end{tabular}




\begin{tabular}{|c|c|c|c|c|c|c|c|}
\hline \multirow[t]{2}{*}{$\begin{array}{l}\text { Trigonella foenum- } \\
\text { graecum } \mathrm{L} \text {. }\end{array}$} & \multirow[t]{2}{*}{ Fabaceae } & \multirow[t]{2}{*}{ Methi } & \multirow[t]{2}{*}{ Herb } & \multirow[t]{2}{*}{ Seed } & Infusion & \multirow[t]{2}{*}{ Oral } & $\begin{array}{l}\text { Soaked seeds are mixed with cornflour meal, and given orally to cure chronic cough } \\
\text { and fever }\end{array}$ \\
\hline & & & & & Decoction & & $\begin{array}{l}\text { Trigonella foenum-graecum L. and Zingiber officinale Roscoe are mixed and fed to } \\
\text { cure joint swelling }\end{array}$ \\
\hline \multirow[t]{2}{*}{ Mentha arvensis $\mathrm{L}$. } & \multirow[t]{2}{*}{ Lamiaceae } & \multirow[t]{2}{*}{ Pudina } & \multirow[t]{2}{*}{ Herb } & \multirow[t]{2}{*}{ Leaf } & \multirow[t]{2}{*}{ Paste } & Oral & $\begin{array}{l}\text { Mentha arvensis } \mathrm{L} \text {. and Allium sativum } \mathrm{L} \text {. are mixed in a ratio of } 2: 1 \text {, and feed after } \\
\text { crushing to cure diarrhea }\end{array}$ \\
\hline & & & & & & Dermal & The whole plant is rubbed into the body of the animal to cure ectoparasite \\
\hline Ocimum tenuiflorum L. & Lamiaceae & Tulsi & Shrub & Leaf & Paste & Dermal & Leaf paste is applied externally to healing wounds \\
\hline \multirow[t]{2}{*}{$\begin{array}{l}\text { Pogostemon benghalensis } \\
\text { (Burm. F.) O. Ktze }\end{array}$} & \multirow[t]{2}{*}{ Lamiaceae } & \multirow[t]{2}{*}{ Rudilo } & \multirow[t]{2}{*}{ Herb } & \multirow[t]{2}{*}{ Leaf, flower } & Powder & Oral & $\begin{array}{l}\text { Leaf and flower are dried in sun. Powder is prepared by crushing them and fed to } \\
\text { cure diarrhea }\end{array}$ \\
\hline & & & & & Paste & Dermal & Leaf and flower are crushed to make a paste, and applied to cure a wound \\
\hline $\begin{array}{l}\text { Lindera neesiana (Wall. } \\
\text { ex Nees) Kurz. }\end{array}$ & Lauraceae & Siltimur & Tree & Fruit & Juice & Oral & The fruit juice is given to cure any weakness \\
\hline $\begin{array}{l}\text { Asparagus racemosus } \\
\text { Willd }\end{array}$ & Liliaceae & Kurilo & Shrub & Root & Paste & Oral & $\begin{array}{l}\text { Tuberous roots are crushed and mixed with cattle feed for any bone related problem } \\
\text { and mastitis }\end{array}$ \\
\hline Linum usitatissimum $\mathrm{L}$. & Linaceae & Aalus & Shrub & Seed & Powder & Oral & $\begin{array}{l}\text { Linum usitatissimum L. and Sesamum indicum L. are fried and crushed to make } \\
\text { powder. It is then fed orally to cure mastitis. Similarly, Powder obtained from dried } \\
\text { seed of Linum usitatissimum L., Sesamum indicum L. and Trachyspermum ammi } \\
\text { (L.) Sprague are mixed and fed with cornflour twice a day to increase milk } \\
\text { production }\end{array}$ \\
\hline Viscum album $\mathrm{L}$. & Loranthaceae & $\begin{array}{l}\text { Hardjor } \\
\text { laharo }\end{array}$ & Climber & Stem & Paste & $\begin{array}{l}\text { Dermal, } \\
\text { Oral }\end{array}$ & $\begin{array}{l}\text { The stem is crushed and paste is applied to the swelling area. It can also be fed by } \\
\text { mixing with ghee and honey }\end{array}$ \\
\hline $\begin{array}{l}\text { Abelmoschus esculentus } \\
\text { (L.) Moench }\end{array}$ & Malvaceae & Bhindi & Shrub & Root & Paste & Oral & Root is crushed and fed to cure urinary related problems \\
\hline \multirow{4}{*}{ Bombax ceiba $\mathrm{L}$. } & \multirow[t]{4}{*}{ Malvaceae } & \multirow[t]{4}{*}{ Simal } & \multirow[t]{4}{*}{ Tree } & Flower & Juice & \multirow[t]{3}{*}{ Oral } & Flower is crushed and fed to cure constipation \\
\hline & & & & Bark & Powder & & $\begin{array}{l}\text { Powder obtained from bark is mixed with powder of pepper and ginger, and then } \\
\text { given orally to cure dysentery }\end{array}$ \\
\hline & & & & Bark & Juice & & Raw bark is crushed to obtain juice and given to remove the placenta \\
\hline & & & & Seed & Paste & Dermal & The seed is ground with mustard oil, and then applied to treat the wounds \\
\hline Corchorus capsularis $\mathrm{L}$. & Malvaceae & Jute Plant & Shrub & Stem & Roast & Oral & Stem is burned, and obtained ash is mixed with mustard, then fed to treat diarrhea \\
\hline $\begin{array}{l}\text { Osbeckia stellata Buch. } \\
\text { Ham ex D. Don. }\end{array}$ & Melastomataceae & Aangaru & Shrub & $\begin{array}{l}\text { Leaf, } \\
\text { Fruit }\end{array}$ & Decoction & Oral & $\begin{array}{l}\text { A decoction of the leaf and fruit twice a day is given to domestic animals for any } \\
\text { kind of weakness }\end{array}$ \\
\hline \multirow[t]{2}{*}{ Azadirachta indica A.Juss. } & \multirow[t]{2}{*}{ Meliaceae } & \multirow[t]{2}{*}{ Neem } & \multirow[t]{2}{*}{ Tree } & \multirow[t]{2}{*}{ Leaf, seed } & Paste & Dermal & Paste is made by crushing leaf and applied to cure ectoparasite, and fed to cure wound \\
\hline & & & & & Decoction & Oral & $\begin{array}{l}\text { Azadirachta indica A.Juss., Artemisia indica } \mathrm{L} \text { and Melia azedarach L. are taken } \\
\text { and cut into pieces, then cooked with cornflour to cure endoparasite }\end{array}$ \\
\hline \multirow[t]{3}{*}{ Melia azedarach $\mathrm{L}$. } & \multirow[t]{3}{*}{ Meliaceae } & \multirow[t]{3}{*}{ Bakaino } & \multirow[t]{3}{*}{ Tree } & \multirow[t]{3}{*}{ Leaf, seed } & Juice & Dermal & $\begin{array}{l}\text { Seed and leaf are crushed to make juice. It is applied by mixing with turmeric and } \\
\text { salt to cure ectoparasite }\end{array}$ \\
\hline & & & & & Decoction & Oral & $\begin{array}{l}\text { Melia azedarach L., Azadirachta indica A.Juss., and Artemisia indica L. are taken } \\
\text { and cut into pieces. It is cooked with cornflour then feed to treat endoparasite }\end{array}$ \\
\hline & & & & & Paste & Dermal & $\begin{array}{l}\text { Seed and leaf are crushed to make a paste. It is applied to cure wound by mixing } \\
\text { with camphor }\end{array}$ \\
\hline \multirow[t]{2}{*}{$\begin{array}{l}\text { Tinospora cordifolia } \\
\text { (Thunb.) Miers }\end{array}$} & Menispermaceae & Ganigurjo & Climber & Stem & Decoction & Oral & $\begin{array}{l}\text { Stem is made into small pieces, then boiled with water and fed to cure chronic } \\
\text { cough and constipation }\end{array}$ \\
\hline & & & & & Powder & & The powder is obtained from dried stem and given orally with water to treat diarrhea \\
\hline
\end{tabular}




$\begin{array}{ll}\text { Artocarpus heterophyllus } & \text { Moraceae } \\ \text { Lam. } & \\ \text { Ficus religiosa } \text { L. } & \text { Moraceae } \\ \text { Ficus semicordata Buch.- } & \text { Moraceae } \\ \text { Ham. ex Sm. } & \\ \text { Morus australis Poir. } & \text { Moraceae } \\ \text { Musa x paradisiaca } \text { L. } & \text { Musaceae } \\ \text { Myristica fragrans Houtt. } & \text { Myristicaceae }\end{array}$

\section{Fraxinus floribunda Wall. Oleaceae}

Oxalis corniculata $\mathrm{L}$.

Oxalidaceae

Sesamum indicum $\mathrm{L}$.

Pedaliaceae
Rukh katar Tree

Peepal Tree

Khanyu Tree

Ban kimbu Tree

Malvoc Kera Herb

Jaifal Tree

Lankuri Tree

Chariamilo Herb

Kalo Til

Herb
Raw

Bark

Leaf

Root

Fruit

Bark

Leaf

Seed
Powder

Raw

Paste

Raw

Powder

Powder

Paste

Juice

Powder
Oral, Ripen jackfruit is fed directly, and the fruit core is applied in teats to cure mastitis

Dermal

Dermal Dry bark is ground to obtain powder and applied to the burn area

Oral Leaves as fodder are given to remove the placenta

Oral Fresh root is crushed to make a paste and fed to animal for treating endoparasite Oral Ripen banana is given to treat mastitis

Oral Powder is obtained from seeds of Myristica fragrans Houtt., Trachyspermum ammi (L.), and Sesamum indicum L., then fed to cure chronic cough, constipation. Solely it is given to increase milk production and urinary problems

Oral Bark is ground to make powder to cure diarrhea

Dermal A paste of bark is applied to treat broken legs and arms of anima

Ocular Juice obtained by pounding fresh leaves is dropped into the eyes for any eye problems

Oral Powder is obtained from seeds of Sesamum indicum L., Trachyspermum ammi (L.) Sprague and Myristica fragrans Houtt, and then fed to cure chronic cough and constipation Sesamum indicum L., Trachyspermum ammi (L.) Sprague and Linum usitatissimum L. are fried and crushed to make powder and fed to cure mastitis and increase milk production

$\begin{array}{llllll}\text { Phyllanthus emblica } \text { L. } & \text { Phyllanthaceae } & \text { Amala } & \text { Tree } & \text { Fruit, leaf } & \text { Paste } \\ \text { Pinus roxburghii Sarg. } & \text { Pinaceae } & \text { Sallo } & \text { Tree } & \text { Latex } & \text { Juice } \\ \text { Piper nigrum L. } & \text { Piperaceae } & \text { Marich } & \text { Climber } & \text { Seed } & \text { Powder } \\ \text { Scoparia dulcis } \text { L. } & \text { Plantaginaceae } & \text { Chini jahr } & \text { Herb } & \text { Stem } & \text { Paste }\end{array}$

Cynodon dactylon (L.) Pers. Poaceae

Dubo

Herb Whole plant

Eleusine coracana Gaertn. Poaceae

Eulaliopsis binnata (Retz.) Poaceae C.E. Hubb.

Hordeum vulgare L. Poaceae

Imperata cylindrical (L.) Poaceae P.Beauv.

Saccharum officinarum L. Poaceae

Kodho

Herb

Seed

Babio khar Herb Whole plant Raw

Jau

Siru

Leaf

Seed

Herb Root

Ukhu

Herb Stem

Leaf

Amriso

Herb

Leaf

(Roxb.) Kuntz

Zea mays $\mathrm{L}$.

Poaceae

Makai

Herb Fruit

Seed

Prunus persica $(\mathrm{L}$.

Batsch.

Rosaceae

Aaru

Tree

Leaf

Rubus ellipticus Sm.
Rosaceae
Aiselu
Raw

Paste is made by crushing leaves and fruit. Then applied to the burn area

Dermal Latex obtained from stem is mixed with mustard oil and applied to wound skin

Ocular Powder is prepared and blown to the eye gently to cure eye-related problem

Dermal The stem is crushed, and the paste is applied to the swelling area. Cloth is generally used to make it attach to the swelling area

Oral Whole plant is fed to livestock twice a day to enhance the lactation

Dermal Paste is made by crushing the whole plant and applied in a wounded area

Oral Seeds are boiled in water and mixed with cornflour meal to cure chronic cough and any weakness

Oral Grass is given raw to cure weakness

Juice Ocular

Decoction Oral

Paste

Oral

Newly born leaf is crushed to obtain juice and used to cure eye-related problems Seed is boiled in water. The obtained Oily material is fed orally to treat mastitis Root is crushed to make a paste and used to cure endoparasite

Juice

Oral Stem is crushed to obtain juice, boiled, and fed by mixing with cornflour to increase milk production

Raw Oral Leaf is given as feed to remove placenta

Raw Oral Leaves as a feed are given to remove placenta

Paste

Decoction

Oral Head smut infected corn is crushed by mixing with lemon juice and fed to treat diarrhea Maize flour is made from corn seed and boiled with salt and water to increase milk production

Juice, Paste Dermal Newly born leaf buds are taken and crushed to make juice. Then it is mixed with camphor and applied when endoparasites are seen. It is also applied to treat wound

Paste

Leaves are crushed to make a paste and applied in the wound area 


\begin{tabular}{|c|c|c|c|c|c|}
\hline \multirow{2}{*}{$\begin{array}{l}\text { Aegle marmelos (L.) Corrêa } \\
\text { Boenninghausenia albiflora } \\
\text { (Hook.) Rchb. ex Meissn }\end{array}$} & Rutaceae & Bel & Tree & Fruit & Paste \\
\hline & Rutaceae & Upiya jhar & Herb & Leaf & Juice \\
\hline Citrus limon (L.) Osbeck & Rutaceae & Kagati & Shrub & Fruit & $\begin{array}{l}\text { Paste } \\
\text { Juice }\end{array}$ \\
\hline Citrus maxima Merr. & Rutaceae & Bhogate & Shrub & Leaf & $\begin{array}{l}\text { Raw } \\
\text { Paste } \\
\text { Juice }\end{array}$ \\
\hline Citrus medica $\mathrm{L}$. & Rutaceae & Bimiro & Tree & Root & Juice \\
\hline $\begin{array}{l}\text { Osyris wightiana Wall. ex } \\
\text { Wight }\end{array}$ & Santalaceae & Nun dhiki & Shrub & Bark & Powder \\
\hline Sapindus mukorossi Gaertn. & Sapindaceae & Ritho & Tree & Fruit & Paste \\
\hline $\begin{array}{l}\text { Diploknema butyracea } \\
\text { (Roxb.) H.J.Lam }\end{array}$ & Sapotaceae & Chyuri & Tree & Root & Paste \\
\hline & & & & $\begin{array}{l}\text { Fruit } \\
\text { Bark }\end{array}$ & \\
\hline Capsicum aппиит $\mathrm{L}$. & Solanaceae & Khursani & Shrub & Fruit & Raw \\
\hline Datura metal L. & Solanaceae & Dhatur & Herb & Fruit & Roast \\
\hline Solanum lycopersicum L. & Solanaceae & Tamatar & Herb & Fruit & $\begin{array}{l}\text { Juice } \\
\text { Raw }\end{array}$ \\
\hline Solanum melongena $\mathrm{L}$. & Solanaceae & Bhenta & Herb & $\begin{array}{l}\text { Fruit } \\
\text { Leaf }\end{array}$ & $\begin{array}{l}\text { Roast } \\
\text { Paste }\end{array}$ \\
\hline Solanum tuberossum $\mathrm{L}$. & Solanaceae & Aalu & Herb & Tuber & Raw \\
\hline $\begin{array}{l}\text { Schima wallichii (DC.) } \\
\text { Korth. }\end{array}$ & Theaceae & Chilaune & Tree & Bark & Powder \\
\hline Urtica dioica $\mathrm{L}$. & Urticaceae & Sisno & Herb & Leaf & Decoctio \\
\hline Vitex negundo L. & Verbenaceae & Simali & Tree & Leaf & Decoctio \\
\hline $\begin{array}{l}\text { Ampelocissus divaricata } \\
\text { (Wall. ex M.A.Lawson) } \\
\text { Planch. }\end{array}$ & Vitaceae & Purreni & Climber & Stem & Raw \\
\hline Cissus repens Lam. & Vitaceae & $\begin{array}{l}\text { Charchare } \\
\text { laharo }\end{array}$ & Climber & Root & Juice \\
\hline Curcuma longa $\mathrm{L}$. & Zingiberaceae & Besar & Herb & Rhizome & $\begin{array}{l}\text { Powder, } \\
\text { Paste } \\
\text { Powder }\end{array}$ \\
\hline $\begin{array}{l}\text { Elettaria cardamoтит } \\
\text { (L.) Maton }\end{array}$ & Zingiberaceae & Alaichi & Herb & Seed & Powder \\
\hline Zingiber officinale Roscoe & Zingiberaceae & Aduwa & Herb & Rhizome & Paste \\
\hline
\end{tabular}

Oral The fruit is crushed and made paste to treat fever

Dermal Leaves juice is applied over the body to remove flea, bug, lice, and external parasites

Fresh twigs leaves are ground with camphor and applied to the wound

Oral Lemon juice is mixed with egg. If head smut infected corn is available then its powder is mixed and given to animal to cure fever

Dermal Juice is rubbed to swelling area

Oral Leaves are crushed and mixed with cornflour to cure endoparasite

Ocular Juice obtained is mixed with salt and applied to eye problem

Oral Juice obtained by pounding root and given orally to treat endoparasite

Oral Dried bark is crushed to make powder and fed to cure joint swelling

Oral Fruit with its covering are cooked with cornflour and water to cure urinary problem

Oral Root is crushed to make a paste and fed to cure fever

Dermal Fruit is crushed and paste obtained is applied to cure mastitis

Bark is ground with water and applied by mixing with camphor to cure the wound

Oral Fruit is directly given to the animal to treat urinary related problem

Oral Fruits are roasted on open fire, and fed to treat diarrhea, dysentery and fever

Dermal Fruit is crushed, and then the juice is applied to the burn area

Oral Fruit is directly fed to livestock to cure endoparasite

Dermal Fruit juice is applied to cure mastitis

Oral The fruit is roasted and fed to animal to cure diarrhea The newly born leaf is crushed and fed to remove the placenta

Dermal Tuber is cut and rubbed externally on burns twice a day

Oral Bark of Schima wallichii (DC.) Korth. and Oroxylum indicum (L.) Kurz are dried, then ground to obtain powder, and given orally to cure diarrhea. Schima wallichii (DC.) Korth. alone is given to cure endoparasite

Oral Leaf is boiled, and water is fed to an animal to cure mastitis and urinary problem

Dermal Boiled extract of the leaf is applied on scabies and other skin infections in animals

Ocular One end of fresh-cut stem is brought near to eye and watery like substance oozing out from stem is let go into eye by blowing air

Ocular Stem is gently crushed to obtain juice and applied to any eye problem

Dermal A dried rhizome is crushed and mixed with mustard oil. Then, applied in burn area, wound and to treat ectoparasite.

Ocular Little powder is blown to the eye to treat eye-related problem

Oral Powder is made by crushing dry seeds and fed to animal to cure fever

Oral, Raw rhizome is crushed and given to cure diarrhea, mastitis. It is crushed with Trigonella foenum-graecum L. to treat joint swelling

Dermal Raw rhizome is ground with camphor to treat wounds 


\section{Plant diversity and uses}

The present study revealed the ethnoveterinary use of 103 plant species belonging 56 families to cure 21 animal ailments. Mostly, plants were collected by local people from forests, marginal land, grassland, and cultivated fields. Out of 56 families, Fabaceae was found to be dominant with 10 plant species similar to the findings of Acharya et al. (2015). This might be due to its higher abundance in the study area and high bioactivity. Fabaceae was followed by Poaceae (8 species), Rutaceae and Solanaceae (5 species each), Cucurbitaceae and Moraceae (4 species each), Anacardiaceae, Apocynaceae, Lamiaceae, Malvaceae, and Zingiberaceae (3 species each). The remaining 45 families had less than 3 species each. In contrast to our study, Raut and Shrestha (2012) found Liliaceae as a dominating family. This difference in observation might be due to different vegetation of the study area or might be due to differences in traditional beliefs. The list of the ethnoveterinary medicinal plants identified in the study area is shown in Table 2. whereas Families with their number of plant species are shown in Table 3.

\section{Plant parts used and their life forms}

It was found that the informants used varieties of plant parts for treating different ailments of animals. However, the most commonly used plant part was leaf (of 32 plant species), followed by seed (of 21 plant species), fruit (of 20 plant species), and bark (of 13 plant species). A study by Malla and Chhetri (2012); Acharya et al. (2015) also found leaf as the most used plant part similar to this present study. A preferred use of leaf might be ease of collection as compared to other plant parts. The leaf is also the center for many physiological processes and contains different metabolites (Tariq et al. 2014). The collection of leaves over other parts have no threat to the survival of the plant (Poffenberger et al. 2010). In contrast to this study, Acharya and Acharya (2010) found maximum use of whole plant whereas maximum use of fruit and seed was found by Raut and Shrestha (2012). The plant parts and the number of plant used reports are provided in Figure 3. In addition to this, the data on the life form of plants indicate that most plant species were herbs (44 species), trees (32 species), shrubs (14 species), and climbers (13 species) (Figure 4). Herbs are available everywhere and easy to collect as compared to other life forms. Herbs were also found to be the prevailing life form in the study by Acharya et al. (2015). It might be due to ease of collection, storage, extraction, and transportation than other life forms. But, in contrast to this study Acharya and Acharya (2010) found climbers as mostly used life form.

\section{Preparation technique and routes of administration}

The application of the medicinal plants as the form of paste formulation was observed for 41 plant species while 25 plant species were used as powder formulation followed by Juice (21 species), raw (20 species), decoction (19 species), infusion (5 species), and roasted formulation (3 species). In contrast to this study, juice was the widely used preparation technique in previous studies in other parts of
Nepal (Acharya and Acharya 2010; Raut and Shrestha 2012).

Table 3. Taxonomic diversity of medicinal plants

\begin{tabular}{|c|c|}
\hline Family name & Number of plant species \\
\hline Acanthaceae & 1 \\
\hline Amaranthaceae & 2 \\
\hline Amaryllidaceae & 1 \\
\hline Anacardiaceae & 3 \\
\hline Apiaceae & 2 \\
\hline Apocynaceae & 3 \\
\hline Araceae & 2 \\
\hline Asparagaceae & 1 \\
\hline Asphodelaceae & 1 \\
\hline Begoniaceae & 1 \\
\hline Bignoniaceae & 1 \\
\hline Boraginaceae & 1 \\
\hline Brassicaceae & 1 \\
\hline Cannabaceae & 1 \\
\hline Capparaceae & 1 \\
\hline Caricaceae & 1 \\
\hline Combretaceae & 1 \\
\hline Commelinaceae & 1 \\
\hline Compositae & 2 \\
\hline Convolvulaceae & 1 \\
\hline Cucurbitaceae & 4 \\
\hline Cyperaceae & 1 \\
\hline Dioscoreaceae & 1 \\
\hline Equisetaceae & 1 \\
\hline Fabaceae & 10 \\
\hline Lamiaceae & 3 \\
\hline Lauraceae & 1 \\
\hline Liliaceae & 1 \\
\hline Linaceae & 1 \\
\hline Loranthaceae & 1 \\
\hline Malvaceae & 3 \\
\hline Melastomataceae & 1 \\
\hline Meliaceae & 2 \\
\hline Menispermaceae & 1 \\
\hline Moraceae & 4 \\
\hline Musaceae & 1 \\
\hline Myristicaceae & 1 \\
\hline Oleaceae & 1 \\
\hline Oxalidaceae & 1 \\
\hline Pedaliaceae & 1 \\
\hline Phyllanthaceae & 1 \\
\hline Pinaceae & 1 \\
\hline Piperaceae & 1 \\
\hline Plantaginaceae & 1 \\
\hline Poaceae & 8 \\
\hline Rosaceae & 2 \\
\hline Rutaceae & 5 \\
\hline Santalaceae & 1 \\
\hline Sapindaceae & 1 \\
\hline Sapotaceae & 1 \\
\hline Solanaceae & 5 \\
\hline Theaceae & 1 \\
\hline Urticaceae & 1 \\
\hline Verbenaceae & 1 \\
\hline Vitaceae & 2 \\
\hline Zingiberaceae & 3 \\
\hline
\end{tabular}


Similarly, different types of vehicles were found to be used for the administration of plant recipes like water, mustard oil, cornflour, curd, and water. Out of them cornflour and water were the most commonly used. The common route of administration was oral, followed by dermal, and ocular. Maximum use of oral route of medication was similar to the findings of Raut and Shrestha (2012). Nasal way of administration was not found in this study. Different preparation techniques and routes of administration with number of plants are shown in Table 4 and Table 5 respectively. Similar to our study, a single plant, as well as a combination of two or more plant species, was used to cure ailments (Acharya et al. 2015).

\section{Informant consensus factor (ICF)}

Informant consensus factors of different ailment categories are shown in Table 6. It was found that the ICF values vary from 0.858 to 0.96 with an average value of 0.926. High informant consensus factor was found for reproductive (0.96), followed by respiratory (0.957), gastrointestinal (0.949) while the least was for urinary problems (0.858). The high ICF value for the reproductive category indicated that reproductive ailments are common in the area. Furthermore, three plant species were used for four ailments categories, eight plant species for three ailments categories, twenty-nine plant species for two ailments categories, and sixty-three plant species were used for single ailment category (Figure 5).

\section{Citation frequency $(\mathrm{Cf} \%)$}

The total number of times that all species mentioned was 2450 times $(\mathrm{N})$. The highest citation frequency was found for Trachyspermum ammi (L.) Sprague 247 $(10.08 \%)$ followed by Myristica fragrans Houtt. 111 (4.53\%), Sesamum indicum L. 109 (4.44\%), Saccharum officinarum L. 107 (4.36\%), and Zea mays L. 97 (3.95\%). The top 20 plant species with the highest citation frequency are provided in Table $7 . \mathrm{n}$ refers to the number of times a particular species was mentioned.

Table 4. Preparation technique with a number of ethnoveterinary medicinal plants identified in the study area

\begin{tabular}{lc}
\hline \multicolumn{1}{c}{ Preparation technique } & Number of plants \\
\hline Paste & 41 \\
Powder & 25 \\
Juice & 21 \\
Raw & 20 \\
Decoction & 19 \\
Infusion & 5 \\
Roast & 3 \\
\hline
\end{tabular}

Table 5. Routes of administration of the ethnoveterinary medicinal plants identified in the study area

\begin{tabular}{|c|c|}
\hline Route & Number of plants \\
\hline Oral & 76 \\
\hline Dermal & 41 \\
\hline Ocular & 9 \\
\hline
\end{tabular}

Table 6. Informant consensus factor by categories of ailments in the study area

\begin{tabular}{llll}
\hline Ailment category & Nur & Nt & ICF \\
\hline Reproductive & 651 & 27 & 0.96 \\
Respiratory & 143 & 7 & 0.957 \\
Gastrointestinal & 454 & 24 & 0.949 \\
Antipyretic & 148 & 9 & 0.946 \\
Parasitic & 385 & 22 & 0.945 \\
General weakness & 43 & 4 & 0.928 \\
Eye & 98 & 9 & 0.917 \\
Dermatological & 329 & 29 & 0.914 \\
Osteological & 113 & 13 & 0.892 \\
Urinary problem & 86 & 13 & 0.858 \\
\hline
\end{tabular}

Table 7. Top 20 medicinal plant species with highest citation frequency

\begin{tabular}{llll}
\hline Botanical name & Local name & n & Cf\% \\
\hline Trachyspermum ammi (L.) Sprague & Juwano & 247 & 10.08 \\
Myristica fragrans Houtt. & Jaifal & 111 & 4.53 \\
Sesamum indicum L. & Kalo til & 109 & 4.44 \\
Saccharum officinarum L. & Ukhu & 107 & 4.36 \\
Zea mays L. & Makai & 97 & 3.95 \\
Artemisia indica L. & Titepati & 95 & 3.87 \\
Cannabis sativa L. & Ganja & 89 & 3.63 \\
Azadirachta indica A.Juss. & Neem & 81 & 3.30 \\
Solanum melongena L. & Bhenta & 80 & 3.26 \\
Artocarpus heterophyllus Lam. & Rukh katar & 77 & 3.14 \\
Marsdenia tenacissima (Roxb.) Moon & Bilajor & 68 & 2.77 \\
Carica papaya L. & Mewa & 64 & 2.61 \\
Melia azedarach L. & Bakaino & 62 & 2.53 \\
Aloe vera (L.) Burm.f. & Ghyukumari & 60 & 2.44 \\
Curcuma longa L. & Besar & 55 & 2.24 \\
Piper nigrum L. & Marich & 47 & 1.91 \\
Musa xaradisiaca L. & Malboe kera & 41 & 1.67 \\
Brassica nigra L. & Tori & 41 & 1.67 \\
Trigonella foenum-graecum L. & Methi & 39 & 1.59 \\
Pisum sativum L. & Simi & 36 & 1.46 \\
\hline
\end{tabular}

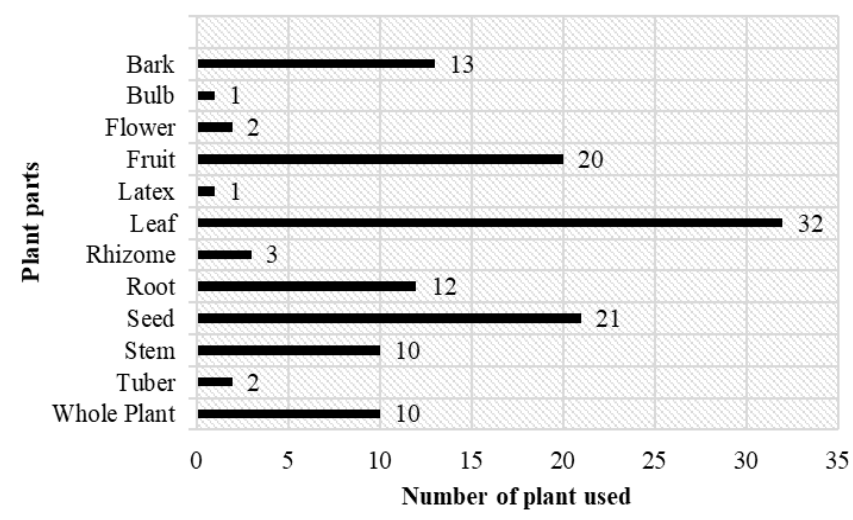

Figure 3. Different plant parts used 


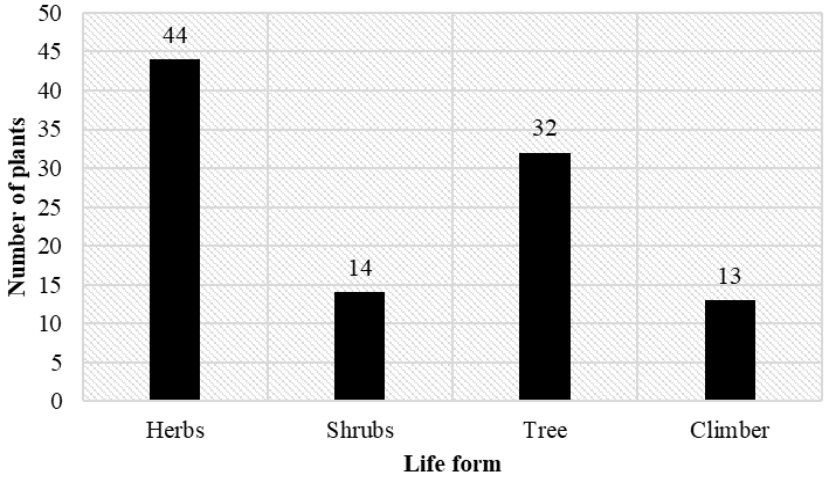

Figure 4. Life form of medicinal plants

In conclusion, traditional medicine is widely practiced by the people of Chhatradev Rural Municipality, Arghakhanchi district as it has become a part of social life and culture, and modern medicine implies a higher cost. People are dependable on the locally available indigenous plant species for the treatment of animals. As the people of younger generations are not acquainted with the knowledge on the use of medicinal plants, the actions should be taken for the documentation of uses of plants, to save the knowledge of ethnoveterinary medicinal plants from generation to generation, and increase the interest of young generation for the study of ethnoveterinary medicinal plants. It is of utmost necessity to involve the community in preserving and rational use of medicinal plants at the local level. Conservation programs should be done from the government level, and study on the use of medicinal plants as well as animals for treating animal diseases is recommended to a bigger extent.

\section{ACKNOWLEDGEMENTS}

We would like to thank Dr. Subodh Khanal for his guidance, and help during the preparation of the manuscript. We are indebted to all the respondents for sharing their indigenous knowledge and cooperation during the fieldwork.

\section{REFERENCES}

Acharya KP, Acharya M. 2010. Traditional knowledge on medicinal plants used for the treatment of livestock diseases in Sardikhola VDC, Kaski, Nepal. J Med Plants Res 4 (2): 235-239. DOI: 10.17660/ActaHortic.2014.1023.4.

Acharya R, Marasini D, Acharya DP. 2015. Traditional knowledge on medicinal plants used for the treatment of domestic cattle in Dhikura village of Arghakhanchi district, Nepal. Adv J Med Plant Res 2 (1): 616.

Adeniran LA, Okpi S, Anjorin TS, Ajagbonna OP. 2020. Medicinal plant used in ethnoveterinary practices in the Federal Capital Territory, North-Central Nigeria. J Med Plant Res 14 (8): 377-388. DOI 10.5897/JMPR2020.6975.

Aryal K, Dhimal M, Pandey A, Pandey A, Dhungana R, Khaniya N, Mehta R, Karki K. 2016. Knowledge Diversity and Healing Practices

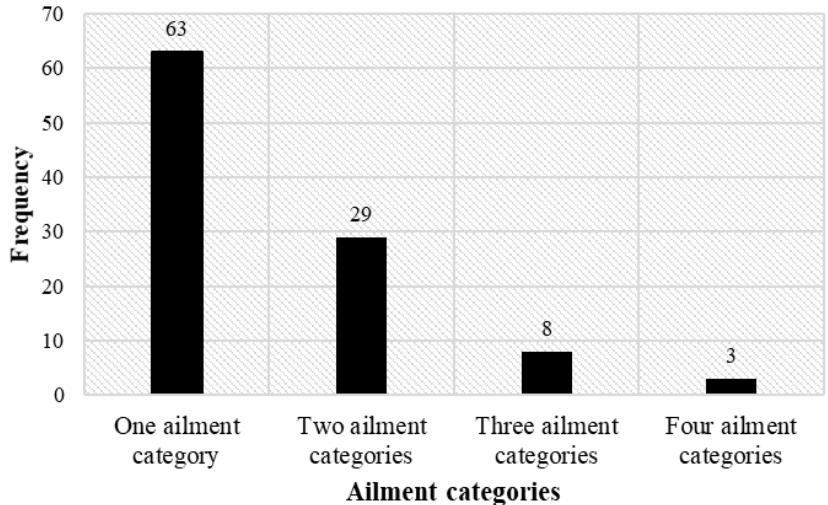

Figure 5. Number of plant species used for number of ailment categories

of Traditional Medicine in Nepal, Nepal Health Research Council, Government of Nepal. http://nhrc.gov.np/publication/knowledgediversity-and-healing-practices-of-traditional-medicine-in-nepal/

Aziz MA, Khan AH, Adnan M, Ullah H. 2018. Traditional uses of medicinal plants used by Indigenous communities for veterinary practices at Bajaur Agency, Pakistan. J Ethnobiol Ethnomed 14 (11): 1-18. DOI: 10.1186/s13002-018-0212-0.

Bartha, SG, Quave CL, Balogh L, Papp N. 2015. Ethnoveterinary practices of Covasna County, Transylvania, Romania. J Ethnobiol Ethnomed 11 (1): 1-22. DOI: 10.1186/s13002-015-0020-8.

Baskota N, Doj Raj K. 2013. Study on Ethnoveterinary Practices in Jumla. In: 9th National Proceedings of Livestock and Fisheries Research, Nepal 277-282.

CBS. 2012. National Population and Housing Census 2011. In Central Bureau of Statistics, Government of Nepal, Kathmandu.

DPR. 2015. Plant resources. In: Lamichchane D, Basukala S, Tandukar U, Lakhey PB (eds.). Bulletin of Department of Plant Resources 37 (1). Department of Plant Resources (DPR), Kathmandu, Nepal.

Hassan N, Nisar M, Kakar SUR, Ul Hassan F, Zhiwei Zhong S, Nong L, Ijaz Khan M, Shuaib M, Wang D, Deli Wang C, Zhong Z. 2017. Determination of informant consensus factor of medicinal plants used as therapy in district Dir Lower Pakistan. J Med Plants Stud 5 (4): 183-188.

Heinrich M, Ankli A, Frei B, Weimann C, Sticher O. 1998. Medicinal plants in Mexico: Healers' consensus and cultural importance. Soc Sci Med 47 (11): 1859-1871. DOI: 10.1016/s0277-9536 (98)00181-6

ISE. 2006. International Society of Ethnobiology Code of Ethics (with 2008 additions). http: //ethnobiology.net/code-of-ethics/

IUCN Nepal. 2000. National Register of Medicinal Plants. IUCN Nepal. https: //portals.iucn.org/library/sites/library/files/documents/2000058.pdf

Katerere DR, Luseba D. 2010. Ethnoveterinary Botanical Medicine: Herbal Medicines for Animal Health. CRC Press.

Khan MA, Islam MK, Siraj MA, Saha S, Barman AK, Awang K, Rahman MM, Shilpi JA, Jahan R, Islam E, Rahmatullah M. 2015. Ethnomedicinal survey of various communities residing in Garo Hills of Durgapur, Bangladesh. J Ethnobiol Ethnomed 11 (1): DOI: 10.1186/s13002-015-0033-3

Malla B, Chhetri R. 2012. Ethnoveterinary practices of some plant species by ethnic people of Parbat District, Nepal. KU J Sci Eng Technol 8 (1): 44-50. DOI: 10.3126/kuset.v8i1.6042.

MOAD. 2017. Statistical Information on Nepalese Agriculture 2073/74 (2016/17). Ministry of Agriculture and Livestock Development, Nepal, Kathmandu.

NAVS. 2015. Ethno-veterinary Medicine: A Concept for Sustainable Livestock Production. National Academy of Veterinary Science, New Delhi, India.

Pan S, Litscher G, Gao S, Zhou S, Yu Z, Chen H, Zhang S, Tang M, Sun J, Ko K. 2014. Historical Perspective of Traditional Indigenous Medical Practices: The Current Renaissance and Conservation of Herbal Resources. Evid Based Compl Altern Med 2014: 1-20. DOI: $10.1155 / 2014 / 525340$ 
Petrovska BB. 2012. Historical review of medicinal plants' usage. Pharmacogn Rev 6 (11): 1-5. DOI: 10.4103/0973-7847.95849

Phondani PC, Maikhuri RK, Kala CP. 2010. Ethnoveterinary uses of medicinal plants among traditional herbal healers in Alaknanda catchment of Uttarakhand, India. Afr J Tradit Compl Altern Med 7 (3) 195-206. DOI: 10.4314/ajtcam.v7i3.54775

Poffenberger M, McGean B, Khare A, Campbell J. 2010. Community Forest Economy and Use Patterns: Participatory Rural Appraisal ( PRA ) Methods in South Gujarat, India. In Field Method Manua Volume 2. Society for Promotion of Wastelands Development, New Delhi.

POWO. 2017. Plants of the World. Royal Botanic Gardens, Kew. http //www.plantsoftheworldonline.org/
Raut B, Shrestha AP. 2012. Ethnoveterinary Practices in Western Morang, Nepal. Intl J Pharm Sci 3 (1): 182-188.

Ryan A. 2014. Documenting Traditional Medical Knowledge. World Intellectual Property Organization, Geneva.

Subedi R. 2017. Ethnobotanical Study of Panchase Protected Forest, Kaski District, Central Nepal. [Dissertation]. Tribhuvan University, Kirtipur. [Nepal]

Tariq A, Mussarat S, Adnan M, Abdelsalam NM, Ullah R, Khan AL. 2014. Ethnoveterinary study of medicinal plants in a tribal society of Sulaiman Range. Sci World J 2014: 1-10. DOI: 10.1155/2014/127526

Weckmüller H, Barriocanal C, Maneja R, Boada M. 2019. Factors affecting traditional medicinal plant knowledge of the Waorani, Ecuador. Susted 11: 1-12. DOI: 10.3390/su11164460. 